\title{
Irregular Immigration Control in Italy and Greece: Strong Fencing and Weak Gate-keeping serving the Labour Market
}

\author{
Anna Triandafyllidou ${ }^{\text {a) }}$ and Maurizio Ambrosini ${ }^{\mathrm{b})}$ \\ a) Professor (part-time), European University Institute, Florence, Italy \\ b) Professor, Department of Social and Political Studies, University of Milan, Italy
}

\begin{abstract}
Italy and Greece have been often blamed by their fellow EU Member States for the excessive permeability of their borders, their inability to stop irregular migration, and their inefficient asylum systems. In addition the two countries have weak internal controls, especially as regards the sectors of the labour market where immigrants are usually employed e.g. agriculture, domestic work, tourism and catering. This article seeks to make sense of these fundamentally contradictory policies that characterise Greece's and Italy's approach to managing migration. The article starts by outlining the common features of Italian and Greek immigration policies and proposes an analysis of immigration control regimes along two dimensions: their internal (within the country's territory) or external (at the border or outside the border) character, and their fencing (stopping) vs. gate-keeping (preventing) nature. Section 3 discusses critically the irregular migration inflows in Greece, the policies implemented to address them and their contradictory results. Section 4 reviews the related policies in Italy and casts light to their inconsistencies. In the concluding section, we highlight the possible explanations for these two countries' lack of direction in immigration management pointing to the opposition between excessively regulated labour markets, large informal economies and strict border controls which however become lax and ineffective once irregular migrants or asylum seekers are within the country.
\end{abstract}

\section{Keywords}

irregular migrations; labour market; migration policies; Southern Europe; regularizations

\section{Introduction}

Irregular migration is a policy priority at both the national and the EU level, though EU countries are not all affected in the same way by the phenomenon. Countries at the geographical periphery of the Union, and in particular southern EU Member States that are close to important migration source and transit countries, face significant inflows from their land and sea borders. The Greek Turkish border emergency with increasing numbers of people crossing during the summer and winter of 2010 the land border at the north-eastern corner of Greece, or the most recent (spring 2011) 'emergency' regarding the arrival of irregular migrants and asylum seekers on the Italian island of Lampedusa fleeing unrest in 
Tunisia and war in Libya are but indicative of the importance of irregular migration management for Italy and Greece.

What is also distinctive of these two countries is however their internally contradictory migration management policies. Indeed both Italy and Greece have been blamed by their fellow EU Member States for the excessive permeability of their borders, their inability to stop irregular migration, and their too frequent implementation of massive regularisation programmes. At the same time both countries have been accused for violating the human rights of irregular migrants and asylum seekers. Italy has been condemned for its illicit accords with Gaddafi's Libya for sending back irregular migrants without examining if they were in need of protection or whether they would be safe when back in Libya. Greece has been the target of strong criticisms (and of a decision of the European Court of Human Rights, on 21 January 2011) because of its problematic asylum system that did not effectively provide people with the possibility to seek asylum and have their case examined according to international standards. In addition the two countries have weak internal controls, especially as regards the sectors of the labour market where immigrants are usually employed e.g. agriculture, domestic work, tourism and catering.

This article seeks to make sense of these fundamentally contradictory policies that characterise Greece's and Italy's approach to managing migration both from a political perspective (why did policy makers and politicians opted for such contradictory policies?) and from a theoretical perspective (distinguishing between fencing and gate-keeping, external and internal control policies). More specifically, the following section outlines the common features of Italian and Greek immigration policies and proposes an analysis of immigration control regimes along two dimensions: their internal (within the country's territory) or external (at the border or outside the border) character, and their fencing (stopping) vs. gate-keeping (preventing) nature. Section 3 discusses critically the irregular migration inflows in Greece, the policies implemented to address them and their contradictory results. Section 4 reviews the related policies in Italy and casts light to their inconsistencies. In the concluding section, we highlight the possible explanations for these two countries' lack of direction in immigration management and outline the need for more in depth analysis of irregular migration in southern European countries with a view to understanding the internal dynamics that condition how migration is managed in these countries.

\section{A Framework for Comparing Greece and Italy}

In order to understand the political context within which migration management policies have developed in the two countries we need to take a step back and look at when Italy and Greece transformed from migrant senders to migrant hosts. In 
Italy the shift took place during the 1980s, becoming evident at the end of the decade, while in Greece it was in the early 1990s after the debacle of the Communist regimes in Central Eastern Europe. The first regularisation programme in Italy took place in 1986 - on the occasion of the first Italian law that speaks of immigration. It was in 1989 when the so-called Martelli Law (Martelli was the then Minister of Interior) was approved by parliament. In 1991, soon after the first boats with large numbers of Albanian irregular migrants began arriving, migration attracted the attention of the media and public opinion. In Greece the first immigration law was voted in 1991 aiming mainly at facilitating expulsion of irregular migrants apprehended near the country's borders. That law was a quick response to the collapse of the Communist regimes in neighbouring countries and the subsequent border crossing of thousands of Albanian men and women into Greece.

Interestingly, ever since both countries' immigration policies share four common main features. First, they are both characterised by a general closure towards economic immigration. For both Italy and Greece immigration is seen as a necessary evil. Hence the related policies aim to mediate or reduce the negative consequences of the phenomenon rather than explore its positive impact and plan ahead.

Second, in both countries legal entries are managed through annual quotas. In the case of Italy such quotas have in fact been converted to mini-regularisation programmes of people already in the country. Generally the implementation of these quotas has responded more to the political moods of the government in power rather than to the real labour market needs, which in any case were higher than the quotas. Similarly in Greece, the quotas are rather small and generally do not respond to the labour market needs not least because their implementation is particularly lengthy and cumbersome. ${ }^{1}$ Such quotas do not respond to the nature of the Greek economy and its businesses that are small and have to react flexibly and quickly to the changing conditions of the market.

Third, both countries have repeatedly resorted to massive regularisation programmes as a way of managing migration a posteriori. Fourth but not less important, both countries have had asylum systems that were inadequate even if they differed in their recognition rates; Greece has had among the lowest recognition rates in the EU (below 3 percent and often below 1 percent) during the past decade while Italy's recognition rate was average or high (e.g. 12 percent approx. in 2005, 60 percent in 2007). ${ }^{2}$ While Italy has a system of protection (SPRAR),

\footnotetext{
1) Triandafyllidou, A. (2011). 'Twenty years of Greek immigration policy', in: A. Triandafyllidou \& T. Maroukis. (eds.), Migration in 21st Century, Athens, Greece: Kritiki, in Greek.

2) Düvell, F. and Vollmer, B. (2011). European Security Challenges, Report prepared for the project Improving EU and US Immigration Systems' Capacity for Responding to Global Challenges: Learning from experiences, available at: http://www.eui.eu/Projects/TransatlanticProject/Documents/Background
} 
it still lacks an organic law on asylum. Greece's shortcomings in asylum matters have been widely known and have attracted a lot of attention during the recent years. ${ }^{3}$ The legal situation has significantly improved by a new law on asylum and irregular migration (law 3907/2011); implementation, however, had just begun in spring 2011, notably some interim measures designed to process slowly but properly a backlog of an estimated 40,000 cases. ${ }^{4}$

Table 1. Dimensions of Migration Control Regimes

\begin{tabular}{|c|c|c|}
\hline & Gate-keeping & Fencing \\
\hline $\begin{array}{l}\text { External } \\
\text { control } \\
\text { policies }\end{array}$ & $\begin{array}{l}\text { - visa procedures } \\
\text { - carrier sanctions } \\
\text { - paper controls at ports of entry } \\
\text { (land border or sea border or } \\
\text { airports) } \\
\text { - procedures to deal with asylum } \\
\text { at the border } \\
\text { - cooperation with countries of } \\
\text { origin and transit to prevent } \\
\text { irregular migration }\end{array}$ & $\begin{array}{l}\text { border controls outside ports } \\
\text { of entry, at land or sea } \\
\text { - cooperation with transit or } \\
\text { origin countries for expulsion } \\
\text { and readmission procedures }\end{array}$ \\
\hline $\begin{array}{l}\text { Internal } \\
\text { control } \\
\text { policies }\end{array}$ & $\begin{array}{l}\text { - } \text { regularisation of illegal status } \\
\text { countum procedures within the } \\
\text { - labour market checks and } \\
\text { controls of access to welfare } \\
\text { and other services }\end{array}$ & $\begin{array}{l}\text { - Internal controls at public } \\
\text { places } \\
\text { - detention, expulsion, removal } \\
\text { and other procedures to } \\
\text { enforce return }\end{array}$ \\
\hline
\end{tabular}

Source: Authors' elaboration on the basis of Vogel. ${ }^{5}$

\footnotetext{
Papers/EU-USImmigrationSystems-Security-bp.pdf last accessed on 27 June 2011; UNHCR (2008), Statistical yearbook 2007, Trends, Geneva: UNHCR.

3) European Council for Refugees and Exile (2008). Sharing Responsibility for Refugee Protection in Europe: Dublin Reconsidered, March 2008, available at www.ecre.org, last accessed on 13 June 2011; NOAS, NHC, and GHM (2008). A gamble with the right to asylum in Europe, Oslo, March 2008; Fundamental Rights Agency (2011). Coping with a fundamental rights emergency. The situation of persons crossing the Greek land border in an irregular manner, available at http://www.statewatch.org/news $/ 2011 / \mathrm{mar} /$ greecefra-report-border-situation-report.pdf, last accessed on 13 June 2011; Pro-Asyl (Ed.) (2007). The truth may be bitter but it must be told: the situation of refugees in the Aegean and the practices of the Greek Coast Guard, Frankfurt: Forderverein Pro Asyl e.V.

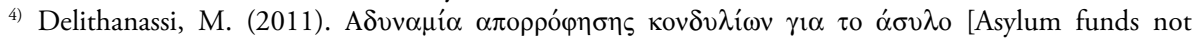
absorbed], Kathimerini, 20 April 2011, available at: http://news.kathimerini.gr/4dcgi/_w_articles_politics_ 1_20/04/2011_439614, last accessed on 10 June 2011.

5) Vogel, D. (2000), 'Migration Control in Germany and the United States', International Migration Review 34(2), pp. 390-422.
} 
In order to analyse the apparently contradictory policy choices of Greece and Italy as regards migration management and in particular irregular migration control, we would like to introduce two sets of distinctions. ${ }^{6}$ The first distinction is to be made between external and internal immigration policies: external immigration policies are those directed at potential immigrants outside the regulating state and at the border, while internal immigration policies are those which concern immigrants who are already inside the nation's borders.

Secondly, irregular migration control policies can be distinguished on the basis of whether they follow a 'fencing' or a 'gate-keeping' strategy: gate-keeping strategies aim at restricting practical legal access to a nation and its institutions, while fencing measures actively target illegal migrants in order to arrest and then expel them. Typically, gate-keeping involves paper controls of people who seek to enter a country or who come voluntarily forward, while fencing involves detecting persons in hiding and trying to deter/stop those who seek to enter without appropriate authorisation.

This article investigates what kind of internal and external control policies the two countries have implemented and how these two sets of policies have been at best not properly coordinated, at worse contradictory. The article exposes the internal contradictions of the Greek and Italian immigration policy and shows how internal and external control, fencing and gate-keeping policies are strongly dependent on one another. However, because these policies touch upon different private interests within the receiving countries, they may develop independently and in a contradictory way when a country has no clear and proactive immigration policy.

\section{External Control Policies in Greece: Sealing the Borders?}

Greece faced important irregular immigration as of the early 1990s after the collapse of the Communist regimes in Central Eastern Europe. During the 1990s, people crossed on foot (with or without the assistance of smugglers) or were smuggled by speed-boats through the Ionian Sea to the north-western Greek coastline and the island of Corfu. The then Conservative government in power reacted swiftly by introducing law 1975/1991, voted in by the Greek Parliament in October 1991, and formally implemented in June 1992. This law, which remained in force until 2001, was eloquently entitled: 'Entry-exit, sojourn, employment, deportation of aliens, procedure for the recognition of alien refugees and other provisions'. The main aim of the law was to make the expulsion of irregular aliens easier and quicker. ${ }^{7}$ Nonetheless irregular migration towards

\footnotetext{
6) Ibid., p. 397.

7) The law concentrated on the development of stricter police controls throughout the country and the border regions in particular. Its main objectives were to prevent the entrance of illegal immigrants and
} 
Greece continued to increase, especially from Albania. There were 370,000 people applying to regularise their stay in Greece at the first 'amnesty' programme that took place in 1998.

The Greek state stepped up its border control efforts by setting up in 1998 a special corps of Border Guards, with a view to tackling irregular migration through the Greek Albanian mountainous border. The setting up of the Greek Border Guard forces and the intensification of the coastguard patrols after 1998 made it more difficult for migrants to enter Greece without help by organised networks. The Border Guards naturally also helped to patrol the northern land borders connecting northern Greece with Bulgaria, the Former Yugoslav Republic of Macedonia (FYROM), and Turkey, which at the time were also prominent avenues for irregular migrant inflows. ${ }^{8}$

During the last years, the more prominent irregular migration pathway for Greece is the one that runs through Turkey. ${ }^{9}$ While irregular border crossings and related apprehensions along the Greek-Albanian border account for a large part of total annual apprehensions (see Table 2), they are easier to deal with since Albanian citizens are returned to Albania swiftly on the basis of the Readmission agreement signed between the EU and Albania ${ }^{10}$ in 2005. Indeed executed deportations/arrests is much higher for Albanian and other European nationals (approximately 67 percent in 2006, 62 percent in 2007, and 58 percent in 2008) in comparison to the rate for people coming from Asian countries (nearly 4 percent being actually expelled or removed in 2006, 3 percent in 2007 and less than 2 percent in 2008) or from African countries (approximately 16 percent of those arrested being expelled/removed in 2006, 8 percent in 2007 and 5 percent in 2008). ${ }^{11}$

The rate of executed expulsions or removals are even more strikingly uneven in 2010, during which 48,177 Albanian citizens were sent back to Albania in a total of 50,175 apprehensions, i.e. at an executed expulsion or removal rate of 96 percent. During the same year, 421 people were expelled to Afghanistan and 676 to

\footnotetext{
facilitate the expulsion of those already present in Greek territory, by means of simplifying the expulsion procedures, giving a certain degree of autonomy to local police and judiciary authorities and also penalising illegal alien stay in the country. The law aimed thus bringing Greece into line with its European partners, co-signatories of the 1990 Dublin convention (ratified by Greece by law 1996/1991) and members of the 1990 Schengen treaty, to which Greece was accorded observer status at the time (see 2001, chapter 5 for further details).

8) Antonopoulos, G. and J. Winterdyk (2006). 'The smuggling of migrants in Greece. An examination of its social organisation', European Journal of Criminology, 3(4), p. 453.

9) Maroukis, T. (2008). Greece, CLANDESTINO project report, Athens: ELIAMEP, available at http:// clandestino.eliamep.gr last accessed on 24 June 2011.

10) See Mackenzie, C. (Ed.) (2006). Return and readmission to Albania. The experience of selected EU countries, report, Tirana, IOM, available at http://www.iomtirana.org.al/en/E-Library/Books/EC\%20 research.pdf, last accessed on 20 June 2011.

11) Data cited here were provided by the Ministry of Interior to the UNHCR Athens office, upon special request. They were given to the author by the UNHCR office. Percentages refer to people 'arrested to be expelled' and not to total number of apprehensions.
} 
Table 2. Irregular Migrant Apprehensions in Greece, Per Year, Per Border and within the Country

\begin{tabular}{lrrrr}
\hline Apprehensions & $\mathbf{2 0 0 7}$ & \multicolumn{1}{c}{$\mathbf{2 0 0 8}$} & \multicolumn{1}{c}{$\mathbf{2 0 0 9}$} & \multicolumn{1}{c}{$\mathbf{2 0 1 0}$} \\
\hline Greek Albanian border & 42,897 & 39,267 & 38,164 & 33,979 \\
Greek FYROM border & 2,887 & 3,459 & 2,355 & 1,589 \\
Greek Bulgarian border & 966 & 1,795 & 1,258 & 983 \\
Greek Turkish land border & 16,789 & 14,461 & $\mathbf{8 , 7 8 7}$ & $\mathbf{4 7 , 0 8 8}$ \\
Greek Turkish sea border & 16,781 & 30,149 & $\mathbf{2 7 , 6 8 5}$ & $\mathbf{6 , 2 0 4}$ \\
Crete & 2,245 & 2,961 & 2,859 & 2,444 \\
Rest of the country & 29,799 & 54,245 & 45,037 & 40,237 \\
TOTAL & 112,364 & 146,337 & 126,145 & 132,524 \\
\hline
\end{tabular}

Source: Compiled by the author on the basis of data by the Hellenic Police, available at www.astynomia .gr. Bold added by the authors.

Iraq - when there were 28,299 apprehensions of Afghani citizens and 4,968 of Iraqi citizens at the border or in the mainland, corresponding to a rate of 13 percent in the case of Iraqi citizens and to less than 1.5 percent for Afghani citizens. ${ }^{12}$ Rates of executed expulsions/removals for other African and Asian countries are within this range of between 1 percent and 10 percent.

Irregular migrants that come via Turkey used to cross the narrow straits that divide the Turkish coasts from several of the Greek islands in the Aegean (e.g. Mytilini, Samos, Chios, Leros). Most recently, however, flows have been diverted to the Evros river area on the north-eastern part of the border in Thrace, mainly crossing through the narrow strip of land where the Greek Turkish border deviates from the river bed. As can be seen in Table 2 (above), in 2010, apprehensions at the Greek Turkish sea border were less than a quarter of 2009 levels while in the Greek Turkish land border they were five times higher in 2010 compared to 2009. This clearly shows a change in the smugglers and irregular migrants' routes with a strong preference for crossing the land border. This strategy is attributed to the completion of the de-mining of the Greek border area near the river Evros which made it an easier route than the crossing the sea to the Aegean islands. ${ }^{13,14}$

12) Rates are calculated by the authors on the basis of data taken from the Hellenic Police web site http://www.astynomia.gr/index.php?option=ozo_content\&perform=view\&id=3665\&Itemid=429\&lang= last accessed on 13 June 2011.

13) Fundamental Rights Agency (FRA) (2011). Coping with a fundamental rights emergency. The situation of persons crossing the Greek land border in an irregular manner, available at http://www.statewatch.org/ news/2011/mar/greece-fra-report-border-situation-report.pdf, last accessed on 13 June 2011.

14) A lot of speculation has been made as to why the irregular migrant smuggles routes have shifted so dramatically and in a short period of time (during the first months of 2010) from the Aegean islands to the Evros river but there is no proper empirical research on the issue so far. While government authorities 
Investment in human resources and technical means has increased in Greece since 2008 with Greece receiving emergency contributions from the European Refugee and the European Border Fund, ${ }^{15}$ engaging more border patrols and improving the technological means for controlling its border as well as improving its reception/detention facilities for irregular migrants. In addition FRONTEX has deployed for the first time ever its RABIT Units ${ }^{16}$ to Greece in the period between November 2010 and March 2011 with the aim of helping the Greek authorities addressing the emergency situation that Greece was facing. There have thus been approximately 200 FRONTEX officers and interpreters working under the command of the Greek authorities with the aim of patrolling the border and collecting information about the smuggling networks. Indeed FRONTEX estimated that 90 percent of the aliens crossing illegally an EU external border to enter EU territory in 2010 were doing so along the Greek Turkish borders. The RABIT units have been replaced as of March 2011 with Operation POSEIDON 2011 whose aim is to assist the Greek authorities in controlling irregular migration flows. ${ }^{17}$

The lack of effectiveness of Greek border control policies and in particular the Greek authorities' inability to expel or remove illegally staying aliens originating from Asian and African states relates to the lack of cooperation on the part of Turkey, which is the main transit country of Asian and African irregular migration towards Greece along the east-to-west route. Turkey has consistently refused to implement the Re-Admission Protocol signed between the two countries in 2002. During the period 2006-2010, Greece had presented ${ }^{18} 3,431$ readmission requests to Turkey, in the context of this Protocol, concerning 62,816 people. Of those 7,359 were accepted for readmission by Turkish authorities, but

and EU institutions have indirectly explained the change as a success of the FRONTEX operations in the Aegean, this does not seem to be a defendable view as FRONTEX has been operating in the Aegean sea for several years before without preventing the increase of irregular migration flows into the country through the Greek Turkish sea borders at the Aegean.

15) Greece has received 2.2 million Euro and 4.9 million Euro (in addition to the normal funding) as an emergency contribution from the European Refugee Fund to reinforce reception capacities in 2008 and 2009 respectively (FRA 2011: 6). The country is also reported (Athens News, 22 May 2009) to have received 13.7 million Euro from the European Border Fund in 2008 to bolster its coast guard fleet and to hire additional border patrol guards at the northern border. Most recently in December 2010 the EU granted an additional 9.8 million European Refugee Fund emergency contribution to cover urgent and immediate needs in reception centres and in developing the new asylum system for processing asylum applications (FRA 2011: p. 6). the FRA report (2011) however laments that Greek authorities are giving priority to setting up the new asylum system and implementing law 3907/2011 rather than improving the reception/detention facilities at the borders, notably in the Evros river area that has faced overcrowding during the last year.

16) RABIT stands for Rapid Border Intervention Teams established by Regulation (EC) 863/2007 of the European Parliament and the Council of 11 July 2007.

17) For more see also: http://www.frontex.europa.eu/newsroom/news_releases/art109.html.

18) Data taken from the Hellenic Police, http://www.astynomia.gr/images/stories/2011/statistics2011/ 0102aithm-epan2006-2010.pdf last accessed on 10 June 2011. 
only 1,281 were effectively re-admitted to Turkey. The strategy of the Turkish authorities has been to respond very slowly and only admitting people through the Greek Turkish land border and not at the port of Izmir too, as foreseen in the Protocol.

Overall it is clear that throughout the last 20 years Greek governments (both of Conservative and Socialist orientation) have been stepping up the efforts to control the country's borders. Initially more attention was paid to the Greek Albanian border which was the main point of entry of irregular migrants. More recently efforts have concentrated on the Greek Turkish border that is now the main point of entry for Asian and African immigrants and asylum seekers to Greece and to the EU. However, Greece's external control policies have had unequal results in the two border areas. In the case of the Greek Albanian border tightened border controls, more human and technological resources and improved cooperation with Albanian authorities have been successful not in stopping the irregular inflows, but at least in detecting and removing/expelling illegally staying Albanian citizens. By contrast despite the heavy investment on the Greek-Turkish border control, the lack of cooperation on the part of the Turkish authorities have made the overall efforts rather unsuccessful. Irregular immigration flows have actually increased in recent years while the effectiveness of expulsions/removals of Asian and African illegally staying aliens has decreased. Overall it is clear that external fencing and gate-keeping strategies are not sufficient to tame irregular immigration flows.

\section{Internal Control Policies in Greece}

The Greek media coverage and political discourse on irregular border crossing has become inflated during the last couple of years, while less attention is paid to irregular migrants within the country and the role that the shadow economy plays in providing plenty of informal work opportunities for them.

Already in the mid 1990s, Greece was practicing massive arrest-and-expel operations targeting Albanian citizens mainly (see Table 3 below). These enforcement exercises were used both as a means to deter irregular migrants from entering, to deter those from staying who were already in the country and compel them to leave on their own initiative and, last but not least, as a means for exerting pressure on the Albanian government with regard to this last's treatment of the Greek minority in Albania. ${ }^{19}$ Checks were enforced usually at public places, more often than not in locations where it was known that irregular migrant workers gathered to find daily employment or to meet co-nationals. They took place under public view and people were loaded on buses and directed to Albania without sometimes having the possibility even to notify their relatives.

19) Triandafyllidou, A. (2001). National Identity and Immigration in Southern Europe, London: Routledge. 
Table 3. Major expulsions from Greece according to nationality (in thousands)

\begin{tabular}{lcrrrr}
\hline Nationality & $\mathbf{1 9 9 1}$ & $\mathbf{1 9 9 2}$ & $\mathbf{1 9 9 3}$ & $\mathbf{1 9 9 4}$ & $\mathbf{1 9 9 5}$ \\
Albanian & 84.3 & 277.0 & 221.0 & 216.5 & 241.2 \\
Bulgarian & - & .4 & 1.0 & 0.8 & 1.4 \\
\hline Iraqi & .2 & .3 & 11.5 & 1.8 & 3.9 \\
Pakistani & - & .3 & 1.5 & 1.6 & 1.8 \\
Romanian & .5 & 2.2 & 2.2 & 2.0 & 0.4 \\
Turkish & - & .1 & .4 & 0.6 & 2.3 \\
Bangladeshi & - & - & - & 0.4 & 0.5 \\
Total & 86.0 & 282.0 & 239.0 & 225.0 & 250.4 \\
\hline
\end{tabular}

Source: Baldwin - Edwards and Fakiolas, 1998: 197.

This policy was discontinued after the early 2000s as Greece implemented its second large regularisation programme in 2001 in which 360,000 applicants took part. As cooperation with Albania over immigration matters improved and as the irregular migrant population settled down and legalised its residence status, internal fencing policies became obsolete. Immigrants were integrated into Greek society and the Greek labour market and actually had overall a beneficial impact on the Greek society and economy. ${ }^{20}$

The situation has however changed since the onset of the global financial crisis in late 2008 which in Greece coincided with a period of increasing social discontent and unrest which was expressed rather massively and violently in the riots of December 2009 in Athens and other major Greek cities. During the first six months of 2009, and in particular after the European election in June 2009 and the significant rise in votes won by the extreme right-wing party LAOS, the then Conservative government in power started a massive operation for arresting and possibly removing irregular aliens from Greek territory. These operations have particularly targeted public places such as metro stations, squares, and crowded neighbourhoods of the city centre, while there have been no measures targeting work sites and sectors where immigrants are known to work, often off-the-book (e.g. in construction and in small factories). These measures have been well-

20) See for instance Lyberaki, A. and T. Maroukis (2005). 'Albanian Immigrants in Athens: New survey evidence on employment and integration', Journal of Southeast European and Black Sea Studies, 5(1), pp. 21-48; Lambrianidis, L. and A. Lyberaki (2001). Albanian immigrants in Thessaloniki, Thessaloniki:

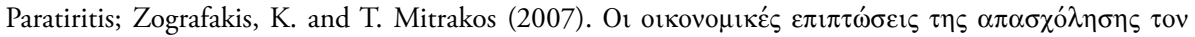

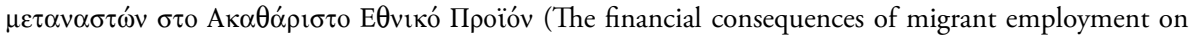
the GNP), Athens: IMEPO, in Greek; Kasimis, C. and A. Papadopoulos (2005). 'The multifunctional role of migrants in the Greek Countryside: Implications for the Rural Economy and Society', Journal of Ethnic and Migration Studies, 31(1), January. 
documented in the press ${ }^{21}$ and actually led to the increase in arrests and effective expulsions noted in the previous section (see Table 1, above).

In addition, while an amendment was passed to law 3537/2005 allowing for irregular migrants to be held in police detention for up to 6 or 12 months if they or their country of origin do not cooperate in their identification and expulsion procedure, police detention centres were so overcrowded that actually irregular migrants were held for shorter periods than before and in any case for not longer than 10 days..$^{22}$

Internal fencing operations have come to the centre of attention during the last year (since the summer of 2010) as the new arrivals apprehended at the Greek Turkish borders, headed to Athens with an expulsion decision at hand. The numbers of irregular migrants and asylum seekers (mainly of Afghani origin) living rough in the centre of Athens have dramatically increased in a period when Greek society and economy are facing the worse crisis of the last 30 years. As these people have been trapped in a state of limbo, without documents and without a speedy processing of their asylum applications (the new asylum law was voted in January 2011 while interim measures aiming to clear the backlog of asylum applications started being implemented in December 2010), ${ }^{23}$ unable to move on to another EU country, they have become easy prey for organised criminal networks. However, the situation has caused social unrest in the central neighbourhoods of Athens providing leeway for extreme right wing groups to take the law in their hands and beat irregular migrants (including women and children). ${ }^{24}$ The Greek police forces have been engaged in internal fencing operations without however implementing any internal gate-keeping policies such as controlling employers and workplaces for irregular employment of aliens and exploitation of their desperate situation. ${ }^{25}$

21) For a review of relevant articles see http://www.migrantsingreece.org/news.asp?chkEN= $1 \&$ chkGR= 18 categ=2, last accessed on 4 October 2009.

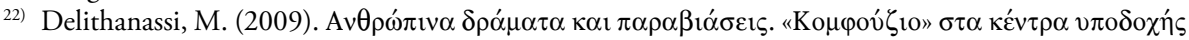
[Human tragedies and violations. Confusion in the reception centres], Kathimerini, 9 September 2009, available at: http://news.kathimerini.gr/4dcgi/_w_articles_ell_1_09/09/2009_328580, last accessed on 24 June 2011.

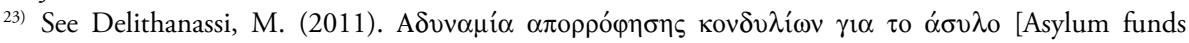
not absorbed], Kathimerini, 20 April 2011, available at: http://news.kathimerini.gr/4dcgi/_w_articles_ politics_1_20/04/2011_439614, last accessed on 10 June 2011.

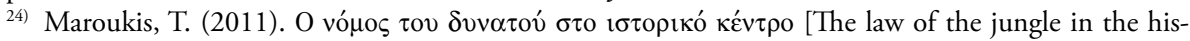
torical centre of Athens], Kathimerini, 17 May 2011, available at: http://news.kathimerini.gr/4dcgi/_w_ articles_columns_1_17/05/2011_442325, last accessed on 11 June 2011.

25) See a BBC (2010). The Battle for Attiqa square [a central square in Athens where irregular migrants gather], at: http://www.youtube.com/watch?v=gPl9PW7ONIQ, last accessed on 13 June 2011; Amnesty International (2010). Irregular migrants and asylum-seekers routinely detained in substandard conditions, London: AI available at: http://www.amnesty.org/en/library/asset/EUR25/ 002/2010/en/07291fb2dcb8-4393-9f13-2d2487368310/eur250022010en.pdf, last accessed on 30 May 2011; also: Maroukis, T. op. cit. and Gousetis, G. (2011). H $\alpha v \tau \iota \mu \varepsilon \tau \alpha v \alpha \sigma \tau \varepsilon v \tau \iota \kappa n ́ ~ \sigma v \mu \mu \alpha \chi i \alpha$ [the anti-immigrant coalition], Kathi- 
One cannot but note a sharp contrast between the great amount of resources and media/political emphasis given to internal fencing strategies in Greece (e.g. random controls in public places), which serve to strongly criminalise irregular residence, and the lesser emphasis given to internal gate-keeping such as labour inspections, as a way to combat irregular migrant employment rather than mere irregular stay. Indeed this selective implementation of internal fencing but not internal gate-keeping policies coupled with strongly advertised external fencing policies has led to a peculiar situation. The longer established, whether legal or irregular (because they arrived illegally and could not regularise their status or because they have fallen into illegality due to unstable employment and hence impossibility to renew their permits) migrants are extensively employed in specific labour market sectors such as agriculture, tourism, catering, other manual jobs and caring/cleaning services - in jobs that natives are not willing to take and where informal employment is the rule rather than the exception. ${ }^{26}$

At the same time both the previous Conservative government led by Kostas Karamanlis and the current Socialist government led by George Papandreou, local authorities in Athens (again both the previously right-wing mayor Nikitas Kaklamanis and to a lesser extent the current left-wing mayor George Kaminis) as well as public opinion ${ }^{27}$ have been agreed: the country cannot take any more immigrants, while a distinction between legally staying and illegally staying aliens is often blurred in the public debate. However these attitudes mainly target the newly arrived, destitute and not yet integrated Asian immigrants (many of whom come from war torn zones like Afghanistan, Somalia or Palestine) while families and businesses keep employing the 'good' Albanian, Ukrainian, Georgian, and of course Bulgarian and Romanian immigrants without really bothering whether they have papers or not. ${ }^{28}$

Over the past two years, migration to Greece has reached crisis proportions. This is related to various issues: the pressing concerns of a permeable border, notably the increased migration pressure on the Greek-Turkish border; a collapsed asylum system, a de facto ghettoisation of certain areas of downtown Athens because of the simultaneous presence of destitute irregular migrants/ asylum seekers and extreme right wing violent groups, and EU pressures to

merini, 17 May 2011 http://news.kathimerini.gr/4dcgi/_w_articles_columns_1_18/05/2011_442448, last accessed on 11 June 2011.

26) Maroukis, T., K. Iglicka and K. Gmaj (2011). 'Irregular migration and informal economy in Southern and Central-Eastern Europe: breaking the vicious cycle?', International Migration Review, forthcoming

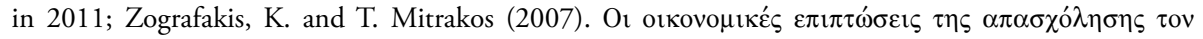

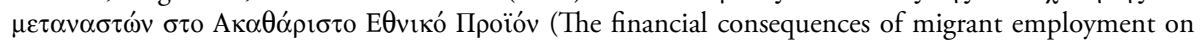
the GNP), Athens: IMEPO.

27) Public opinion survey conducted by the company Public Issue on behalf of the Kathimerini daily, in January 2010; and January 2011, available at: www.publicissue.gr last accessed on 23 June 2011.

28) For a more general discussion see Triandafyllidou, A. and T. Maroukis (Eds.) (2011). Migration in the 21st Century, Athens: Kritiki, in Greek; and for a comparative perspective see Maroukis, T., K. Iglicka and K. Gmaj, K. (forthcoming 2011). 
improve reception facilities as well as border controls. All these migration related developments have been taking place in and exacerbated by an acute economic crisis while settled migrants were faced with increasing unemployment and decreasing wages. ${ }^{29}$

These simultaneous developments have actually somehow carried the Greek immigration policy backwards rather than forward, to the period of 1990s when both Conservatives and Socialists saw immigration as a phenomenon that could be eradicated - as if immigrants could possibly be all forced to return to their countries of origin - and that perceived migration as only having negative consequences for Greece. The rise of extreme right wing forces, both at the national level (represented by the extreme right wing party LAOS which obtained 5 percent of the national vote in the November 2009 election) and at the local (the political formation of 'Golden Dawn' has for the first time elected 2 local councillors at the municipality of Athens in the local elections of November 2010), has also contributed to this change in direction. Thus, the current public debate sees migration as one of the problems that are plaguing Greece at this moment and not as part of the solution.

\section{External Control Policies in Italy}

Italian immigration control efforts have been stepped up in recent years, like in Greece, as the centre right wing coalition government of Silvio Berlusconi supported by the extreme right wing populist party of Lega Nord has made the fight against irregular migration one of their preferred campaigning topics. Indeed the question of migration and security has been an important topic for the last national election (2008), so that the restrictive Bossi Fini law (Law 189/30 July 2002) voted by the then centre right wing government in 2002 was further reinforced by the so called 'security package' of the Minister of Interior Roberto Maroni introduced with two laws (Law 125/24 July 2008 and Law 94/15 July 2009).

The new laws have provided the introduction of irregular stay status as an aggravating circumstance in trials concerning immigrants prosecuted for other crimes; the definition of unauthorized presence in the country as a crime; the prohibition of all administrative acts, including marriage, for undocumented immigrants and the introduction of the possibility of territorial surveillance by citizens' associations (the so-called citizen patrols, ronde in Italian). In addition the new law extended the detention period of irregular migrants in 'identification

\footnotetext{
29) Triandafyllidou, A. and D. Lazarescu (2009). The Impact of the Recent Global Economic Crisis on Migration. Preliminary Insights from the Southeastern Borders of the EU (Greece), CARIM Analytic and Synthetic Notes, No. 40, Florence: CARIM, available at: http://cadmus.eui.eu/bitstream/handle/1814/12995/ CARIM_ASN_2009_40.pdf?sequence=1, last accessed on 27 June 2011.
} 
and expulsion centres' to a maximum of six months. Some of these new policies were later annulled by the Constitutional Court, including the so called citizen patrols, the introduction of irregular stay status as an aggravating circumstance for other crimes, and the obligation to leave the country for apprehended irregular migrants even if these did not have the financial means to pay for their trip.

Bossi-Fini Law (law 189/2002) had introduced already in 2002 a closer link between residence and work (demanding that immigrants have, among other things, job stability that contrasts with the flexibility that the labour market imposes on them), while fighting irregular immigration in a more emphatic and vigorous manner. The law requires that the immigrant has a long term work contract to be able to renew her/his stay permit for a 2 -year period. This provision is in contrast with the reality of the labour market which offers temporary work contracts especially in the sectors where immigrants are predominantly employed such as construction, agriculture, tourism, catering and cleaning services. In the domestic work sector in particular immigrants cannot 'prove' that they have worked the required amount of hours/days as work is largely informal and with lower welfare contributions than the hours/days actually worked. Thus, when the day of the stay permit renewal comes near immigrants have to look for an employer that is willing to comply with the requirements of the law. If they fail, they are likely to lose their permit.

Although, as Finotelli and Sciortino ${ }^{30}$ argue, 'Italy is one of the very few European countries willing to acknowledge the need of an active entry policy and it has actually implemented comparatively liberal provisions for irregular immigrants in many social services', the immigration laws of 2002 and in particular of 2009 have changed the rhetoric. Immigration is now framed as a question of security and public order. Immigrants are presented as a population that is potentially dangerous and that needs to be under surveillance. Immigration is tolerated so long as it responds to the needs of the labour market, in particular the needs of Italian families for carers and cleaners, while naturalisation policy remains particularly restrictive and overall integration efforts rather weak. ${ }^{31}$

These conditions create what Calavita ${ }^{32}$ calls an 'economy of otherness' in which immigrants are subordinated to a system that benefits from their work while conceding them very limited rights. This securitised view of immigration legitimises some of the street-level bureaucracy's attitudes, the proliferation of checks and controls at the expense of immigrants; ${ }^{33}$ without however cracking

\footnotetext{
30) Finotelli, C. and G. Sciortino (2009). 'The Importance of Being Southern: The Making of Policies of Immigration Control in Italy', European Journal of Migration and Law 11 (2009) p. 121.

31) Zincone, G. (2006). Familismo legale. Come (non) diventare Italiani, Roma-Bari: Laterza.

32) Calavita, K. (2005). Immigrants at the margins, New York: Cambridge University Press.

33) Aime, a leading Italian anthropologist, wrote: “(...) Emmanuel Bonsu Foster was at a public garden that day of October 2008. At a public garden of the civil and democratic city of Parma. But he was not sitting down, 'he was talking on the phone, making gestures, walking up and down' said the mayor of Parma, Pietro Vignali. And then 'the school was starting at $7 \mathrm{pm}$. What was he doing in the park at $5 \mathrm{pm}$ ?'
} 
down on the underground economy that employs a significant part of them ${ }^{34}$ as is also confirmed by quantitative studies on. ${ }^{35}$

During the last couple of years, this policy line has been further reinforced. the deployment of troops on the streets of major cities and 'difficult' neighbourhoods for law-enforcement purposes, the reduction of the fund for immigrants' integration to five million euros, shifting resources to the fight against 'illegal' immigration; agreements with Libya for the repression of migrants and refugees arriving by sea, which are always and without distinction defined as 'illegal' (clandestine). ${ }^{36}$ There has been in other words a clear intensification of both internal and external fencing policies.

Within this post-2008 context of strong security emphasis the surveillance of Italian shores has taken up a symbolic importance. The popular wisdom is that irregular migrations arrive to Italy from the sea, because of the difficulties in patrolling the extensive Italian shores especially where important countries of origin/transit are geographically close (e.g. Libya in the case of Lampedusa and Sicily and formerly Albania, as regards Otranto in the Apulia region). ${ }^{37}$ However, the reality is that most irregular migrants arrive in Italy (as in other EU countries) legally with a tourist visa, with a fake visa or passport or with a student visa. ${ }^{38}$ Still the media continue to present the arrival of these 'boats of fortune' packed with people from Albania in the 1990s and more recently from northern Africa as the main influx of irregular migrants.

asked the mayor. As if to say that there were evident and sufficient reasons to believe that he was up to something suspicious and hence [it was justified] that the police arrested this 22 year old from Ghana (who attends an evening schools and works as a volunteer in a local centre for drug addicts), got him to undress, beated him up and then gave him back his personal belongings in an envelope with the name: EMANUEL NIGGER. A black eye, but maybe he fell and got hurt say the authorities. An envelope with this name, but maybe he wrote it himself, they argue (...) EMANUEL NIGGER. 'Maybe they had not understood well his last name', said a police person, 'that word 'nigger' was just to identify him' (Aime, M. (2009). La macchia della razza, Salani ed., p. 51).

34) Finotelli, C. and G. Sciortino (2009). 'The Importance of Being Southern: The Making of Policies of Immigration Control in Italy', European Journal of Migration and Law 11 (2009) p. 127.

35) Fondazione Ismu (2011). Diciasettesimo rapporto sulle migrazioni 2011, Milano: Franco Angeli.

36) In all official communications of the Italian Ministry of Interior people arriving with the boats of fortune through the southern Italian sea borders are categorised as 'clandestines' without any distinction regarding their reasons for leaving their country of origin/residence.

37) Fasano, F. (2009). Country Report Italy. Country report prepared under the research project CLANDESTINO Undocumented Migration: Counting the Uncountable. Data and Trends Across Europe, funded by the 6th Framework Programme for Research and Technological Development under Priority 7 'Citizens and Governance in a Knowledge-Based Society', Research DG, European Commission.

38) Düvell, F. (2006). 'Irregular migration: a global historical and economic perspective', in: F. Düvell (ed.) (2006), Illegal Immigration in Europe: Beyond Control, Houndmills: Palgrave/MacMillan, pp. 14-39. According to the data presented in the statistical dossier Caritas Migrantes (2010), only 5\% of all irregular immigrants arrived in Italy by crossing illegally the sea borders; see also Ruspini, P. (2009). 'Italy', in: ICMPD, REGINE. Regularisations in Europe. Study on practices in the area of regularisation of illegally staying third-country nationals in the Member States of the EU, International Centre for Migration Policy Development (ICMPD), Vienna: ICMPD, Appendix A, p. 71. 
The almost complete stop of irregular migration from Libya to Lampedusa and Sicily since 2009 and until January 2011 was presented by the government as a complete stop of irregular migration to the country and an important policy victory of the government in its efforts to 'fence off' the country from irregular migrants. The UNHCR has strongly condemned the Italian accords with Libya, and in particular the forced refoulements at sea, back towards the Libyan coasts, which actually prevented potential asylum seekers from filing an application and returned them to an unsafe country like Libya. Laura Boldrini, spokesperson of UNHCR in Italy, has fought actively against the Italian government's policy. Her critics are published in her book ${ }^{39}$ where she argues that while the Italian government has managed to stop the irregular immigration flows from Libya it has also prevented many people in need of international protection to file an asylum application in the country. The Italian government has refused these accusations of the UNHCR and other international organisations even if this controversy has significantly deteriorated the relationship between the Italian authorities and the UNHCR. ${ }^{40}$

It is worth noting that the emphasis on external fencing policies and the increased resources allocated to them have not been matched by an increasing efficiency of these policies. The Dossier Caritas-Migrantes ${ }^{41}$ records 14,063 repatriations in 2009, i.e. a 20 percent decline from $2008(17,880)$. At the same time a new regularization programme was implemented in September 2009 targeting, in theory, only irregular migrant domestic workers. There were 295,000 applications for regularization, which means that for every migrant effectively expelled some 20 migrants could be regularized. The last regularisation is still in process, two years after its conclusion. The reasons for this delay include poor human resources assigned to the agencies that had to deal with the applications, the contrasted interpretations of certain requirements for the regularisation of an irregular migrant domestic workers, and hence the need to seek recourse to the courts to solve them. Actually things could not be very different: Italy has a total of 1,800 places in the identification and expulsion centres, too few compared to the declared intention to combat irregular migration. Of the approximately 11,000 immigrants detained in 2009 , only 38 percent have been expelled, despite having extended the maximum detention time to 6 months (now 18, like in Greece). ${ }^{42}$

\footnotetext{
39) Boldrini, L. (2010). Tutti indietro, Milano: Rizzoli.

40) The Minister of Defense, La Russa, has commented on the UNHCR: '[it is] one of these organisations that nobody cares for until the Press decides that they are important' [uno degli organismi che non contano un fico secco, finché la stampa non decide che conta], translated by the authors, Il Messaggero, 16 May 2009. The head of the Senate group of the governing PdL party, Gasparri, added the following day: 'We do not understand who is this Ms Boldrini and in whose name she is speaking. To speak in line with my colleague La Russa, we do not care [about what she says]' [Non si capisce a che titolo parli questa signora Boldrini e, per dirla con La Russa, ce ne freghiamo], Corriere della Sera, 17 May 2009.

41) Caritas-Migrantes (2010). Immigrazione. Dossier statistico 2010, Roma: Idos.

42) Ibid.
} 
The government's aggressive rhetoric ('We must be tough against illegal migrants' $)^{43}$ promulgates measures which should put this restrictive will into practice, but in fact does not call into play the necessary resources to implement the announced policies. It cannot actually mobilize these resources given the enormous costs that this would entail ${ }^{44}$ and the strong interests involved, including those of Italian families with elderly and children who need care. Indeed, the windows of opportunity opened by amnesties or regularizations represent the counterpart to the limited effectiveness of deterrence.

In this context, the strategy of irregular migrants is to evade the controls, waiting patiently for a favourable opportunity, and finally to take advantage of the right moment to regularize. Indeed in this Greece and Italy ${ }^{45}$ are very similar in the sense that a period of undocumented stay and of informal work is almost a necessary stepping stone to a legal stay permit and a normal job, some sort of 'toll' to pay in order to have access to the formal labour market and possibly to better living conditions.

The success of the Italian government's external fencing policies has been overrun by the Arab spring and its aftermath notably the flight of approximately 20,000 Tunisian citizens and about 19,000 sub Saharan Africans ${ }^{46}$ escaping the war in Libya since late January this year. The Italian government had not prepared the necessary infrastructure for receiving these irregular migrants and asylum seekers. The reception centre in Lampedusa had been dismantled since it was believed that irregular migrants influx from Libya had been stopped for good. Thus, the first arrivals in late January and February were assisted by the inhabitants of the island, and people had often had to sleep under the blue sky for several days before being transferred elsewhere.

The government has initially presented the arrivals as a tragic emergency (the Prime Minister Berlusconi has spoken of a 'human tsunami' $)^{47}$ but several leading figures of the Lega Nord party (which participates in the government) have used

\footnotetext{
43) The Interior Minister Maroni declared: 'we have to be tough, determined, not good to oppose clandestine migration and impose the rule of the law' [Per contrastare l'immigrazione clandestina non bisogna essere buonisti ma cattivi, determinati, per affermare il rigore della legge], Corriere della Sera, 2 February 2009.

44) The daily Il Sole 24 Ore, (newspaper of Confindustria, the most important association of Italian employers) wrote on 20 August 2010: The management of the identification and expulsion centres costs about 200,000 Euro each day. The estimated cost is 40-45 Euros per day per person. These numbers include also the cost of the reception centres for asylum seekers. The detention of irregular migrants is actually between 72,000 and 81,000 Euros per day. But if the number of available beds is multiplied by 10 (and they would still be insufficient to host the irregular migrants, currently estimated at half a million) the cost would be more than 700,000 Euro per day, or 250 million per year, without including here the cost of returns to the country of origin nor the salaries of the police agents working in these centres. 45) Glytsos, N.P. (2005). 'Stepping from Illegality to Legality and Advancing toward Integration: The Case of Immigrants in Greece', International Migration Review, 39(4), pp. 819-840.

46) See UNHCR (2011). News release, available at http://www.unhcr.it/news/dir/26/view/1003/jolie-eguterres-a-lampedusa-alla-vigilia-della-gmr-2011-100300.html, last accessed on 25 June 2011.

47) See corriere.it, 1 April 2011.
} 
a harsh language, notably the Lega Nord's leader Umberto Bossi demanded 'immigrants out of here' [Immigrati föra da i ball]), ${ }^{48}$ some have even proposed to open fire on the arriving rickety boats. ${ }^{49}$

In early April, however, the government has decided to change policy and to issue temporary permits (of six month validity) for those who had arrived until 5 April 2011, with a view that Tunisian immigrants in particular might leave for France, where they had family and friends. This decision of the Italian government caused a crisis in Italian-French relation. At the same time this decision has caused outrage among the supporters of the Lega Nord party. Indeed the day after the issuing of the decree on the temporary permits the Lega Nord radio channel Radio Padania has had to interrupt the programme in which the audience is invited to have their say to avoid transmitting insults towards the Minister of the Interior, Roberto Maroni.

For those who arrived after 5 April 2011 from Tunisia a policy of forced returns and expulsions was adopted. Those were implemented partially as often immigrants manage to disappear in the country. By contrast, those arriving from Libya have sought asylum and have been received as people in need of international protection even if the whole issue caused tensions too. ${ }^{50}$

\section{Internal Control Policies in Italy: Strong Fencing but Weak Gate-keeping}

It is worth however turning our attention to the policies of internal control which have for long been the weaker ring in the chain of migration control policies in Italy but which have been beefed up since the 'security package' introduced by the Berlusconi government in 2009.

Indeed internal gate-keeping policies have developed at the local level through measures adopted by local authorities that aim to separate the immigrants from the rest of the resident population. Specific prohibitions concerning immigrants only have been introduced (even if their target is implicit or hidden), setting up special screening procedures or limiting their access to benefits and resources of local social policies. For obvious reasons, undocumented immigrants are a privileged target of policies concerning urban security. The new rules, included in the security package and strongly demanded by local authorities, have given more

\footnotetext{
48) La Repubblica, 29 March 2011, Roma.

49) The MEP Francesco Speroni in a Radio 24 programme: 'Europe is using weapons in Libya.... We are being invaded, there are people who come to Italy without a permit, violating all the rules. At this point we can use all possible means to send them back, we may also use weapons' [In Libia l'Europa non sta usando le armi?... Noi siamo invasi, c'é gente che viene in Italia senza permesso, violando tutte le regole. A questo punto vanno usati tutti i mezzi per respingerli, eventualmente anche le armi], 12 April 2011, http://notizie.tiscali.it/articoli/cronaca/11/04/13).

50) Ambrosini, M. (2011). 'Quelle parole in libertà sui migranti', La Voce-info, 15 April 2011 (www.lavoce info).
} 
powers to the mayors on the issue of urban security. Thus, aspects of combating crime were extended to include repression of behaviours that can disturb or annoy Italian citizens. This resulted in 788 orders, issued between the summer of 2008 and that of 2009 by 445 Municipalities involved, mostly concentrated in the northern regions of Lombardy, Veneto and Friuli, but also involving for instance the region of Emilia-Romagna governed by the centre-left wing coalition. While the main areas of intervention have focused on prostitution, alcohol abuse, vandalism and begging, their targets have in reality been the weakest and most excluded sections of the immigrant populations.

A pilot study looking at 70 different cases which involved 47 different local authorities in the region of Lombardy, ${ }^{51}$ has shown how the measures taken to protect the 'security' of the citizens were directly targeting irregular migrants and could be characterised as internal fencing strategies. One type of these new internal controls involved the local authorities and the police: they called into play for instance, urban transport controls with joint teams of ticket inspectors and police officers targeting irregular migrants who did not have a valid ticket (Milan), issuing a $€ 550$ reward for traffic controllers who would stop an irregular immigrant (in the town of Adro); and an operation called 'White Christmas' in the small town of Coccaglio when inspections in private homes were allowed (to identify irregular migrants).

A second and most worrying type of internal fencing practices involved citizens themselves. Thus for instance there was an initial mobilisation of citizens to form the neighbourhood patrols with the aim of identifying and terrifying irregular migrants. In the town of Cantú, a special free-of-charge telephone number was introduced for callers wanting to report the presence of irregular immigrants. And in San Martino dall'Argine there were public official communications by the local authorities inviting citizens to report irregular migrants.

Even if Prefects and the UNAR (the National Agency against Racial Discrimination) on one hand, and Catholic organisations, trade unions and various antiracist movements on the other, have mobilised against these initiatives, rending several among them ineffective, the emphasis on combating irregular migration has largely remained while any concern for the integration of irregular migrants (estimated at half a million in 2010 ${ }^{52}$ was eliminated.

This strong enforcement of internal and external control policies mainly of a fencing character is not matched however in Italy, like in Greece, by an equally strong commitment to internal gate-keeping policies that would actually affect the domestic labour market. During the last 20 years the Italian economy has

51) Ambrosini, M. (2011). 'We are against the multiethnic society': policies of exclusion at the urban level in Italy, paper presented at the GEITONIES conference Generating Tolerance and Social Cohesion: Comparative Perspectives on Interethnic Coexistence in the City, Lisbon, 28-29 April 2011.

52) Fondazione ISMU (2011). Diciasettesimo rapporto sulle migrazioni 2011, Milano: FrancoAngeli; Fasani 2009. 
produced a high number of low skill jobs that natives were not willing to take and which were filled by immigrants to a large extent. ${ }^{53}$ There has thus been a clear segregation of the labour market; as in Greece migrants occupy specific sectors of the labour market like the caring and cleaning sector, agriculture and low skill manual jobs. ${ }^{54}$

While one could have anticipated a strong contrast between the attitude of lay people - inimical to immigration - and that of employers (smaller or larger) favourable to a much needed immigrant labour force - in reality there is no such contrast, but rather Italian society is marked by a strong ambivalence because of the pivotal role of Italian families who are both lay people against immigrant but also employers in great need of immigrant carers/baby sitters/cleaners. ${ }^{55}$ Indeed the Italian welfare system is largely based on the role of the family and in particular of the women as spouses, mothers and daughters who provide for the necessary unpaid caring and cleaning work in the household. These needs are however now increasingly taken up by immigrant women employed by the families to take up these functions while the women of the families take up paid jobs outside the home. ${ }^{56}$ It is also worth noting that the centre right wing government has made sanctions for irregular migration more severe on paper while however reducing labour controls on employers, thus allowing tacitly for more informal employment at a period of economic crisis. This lack of internal gate-keeping policies comes in stark contrast with the strong emphasis on the internal fencing strategies outlined in the previous paragraphs.

Indeed this contradiction between internal and external fencing policies coupled with a lack of internal gate-keeping policies (confirmed by the implementation of six regularisation programmes in 22 years) is very similar to the migration control regime adopted by Greece and indeed also by Spain. ${ }^{57}$

As far as amnesties of undocumented migrants in Europe are concerned, Italy closely competes with Spain for a double record: the highest number of general regularization processes (five programs since 1986$)^{58}$ and the largest number (relatively to the resident migrant population) of immigrants who obtained a legal status through one of these programs.

\footnotetext{
53) Reyneri, E. and Fullin, G. (2010). 'Labour market penalties of new immigrants in new and old receiving West European Countries', International Migration (49)(1), pp. 31-57.

54) Calavita, K. (2005). Immigrants at the margins, New York: Cambridge University Press.

55) Ambrosini M. (2011). 'Undocumented Migrants and Invisible Welfare: Survival Practices in the Domestic Environment', Migration Letters, 8(1), pp. 34-42.

56) Andall, J. (2000). Gender, Migration and Domestic Service. The Politics of Black Women in Italy, Aldershot: Ashgate; Düvell, F. (2006). 'Irregular migration: a global historical and economic perspective', in F. Düvell (ed.) (2006). Illegal Immigration in Europe: Beyond Control, Houndmills: Palgrave/ MacMillan, pp. 14-39.

57) Quoted from Fasano (2009), supra note 37, p. 13.

58) Another amnesty was enacted in September 2009; a first amnesty, concerning only 5,000 people, was implemented in 1982 (Ruspini, P. (2009)).
} 
What is however peculiar of Italy is not only the size of its regularisation programmes (four 'amnesties' implemented between 1986 and 1998 concerning 790,000 people, 630,000 regularisations in 2002 alone and still about 300,000 applications still in process after the last regularisation of 2009) but also the power attributed to employers in recent 'amnesty' programmes to regularise their workers or not. The Italian regularisation programmes give the employer (be they a company or a family), the possibility to regularise the immigrant man or woman who works for them, and ask them in return to pay a fine that goes towards the coverage of the welfare contributions that they had not paid thus far. In other words, regularisations do not target the immigrant but rather offer an opportunity to the employer who is the one to actually decide on the immigrant's fate. In fact it often happens that it is the immigrant that pays the fine and that some employers accept to provide this as a 'service' upon payment, while they do not really employ the specific migrant.

The same is true with the annual quotas ( $i$ decreti flussi) in which an employer invites an immigrant to come to Italy to work for them (in domestic care or in some other type of job, in agriculture or in a business). In reality the employer invites an immigrant that is already working for them informally. ${ }^{59}$

Actually since 2002 employers played a pivotal role in enabling the immigrants working for them to legalise their status. This was indeed an indirect but rather clear indication of the contradictions built into the Italian immigration control policies: while external and internal fencing has been strengthened in recent years, internal gate-keeping has been selective, leaving it to the labour market and to Italian employers themselves to decide whether to implement the gate-keeping or not.

\section{Concluding Remarks}

This article argues that while irregular migration through unlawful border crossing attracts the highest media visibility, and thereby leads to the conclusion that more effective border control or internal enforcement policies (i.e. external and internal fencing strategies) are necessary for combating irregular migration, a more careful examination indicates that such policies are not effective since the driving force of irregular migration is within society and has to do more with the economy and the labour market rather than with border controls.

First and foremost most irregular migrants do not cross the borders illegally but rather arrive through legal channels with a tourism visa, a student visa, without a visa, with a fake passport or visa. ${ }^{60}$ Thus even 'efficient' accords like the one

59) Ambrosini, M. (2010). Richiesti e respinti. L’immigrazione in Italia come e perché, Milano: Il Saggiatore.

60) Fondazione ISMU (2011). Diciasettesimo rapporto sulle migrazioni 2011, Milano: FrancoAngeli; 
between Italy and Libya are of limited value while their 'cost' in terms of human rights violations and humanitarian crisis is very high.

Second, border controls attract the public eye but do not manage to tame the flows, especially given that once irregular migrants arrive in a country, they are often non-deportable because their identity cannot be established. Moreover, when the source or transit countries from which they come do not cooperate, returning these migrants to their countries of origin becomes virtually impossible, so that the only thing to do is set them free after a short period of police detention. Following from the Return Directive, of course, EU Member States have to either forcibly expel irregular migrants or issue them with a temporary residence document as Italy has done in April 2011 and as the Greek law 3709/2011 foresees.

Detention periods have recently been extended in both Italy and Greece up to 18 months, however actual detention periods are a few days on average for the simple reason that the capacity of detention centres is very limited and detention as such is very costly in material and human resources (police officers, cost of managing the detention centres).

Third, irregular as any other migration is driven not only by push factors in the countries of origin but also by strong pull dynamics in the countries of destination as well as various determinants in-between (networks, smugglers, etc.). Thus, reinforcing the external fencing or even the internal fencing practices (as particularly evident in the case of northern Italian regions but also in the city of Athens in the last couple of years) is not an adequate strategy as these practices do not touch upon the labour market and the vested interests in migrant (informal) employment.

The hidden albeit strong influence of the labour market is actually confirmed in both Italy and Greece by the conspicuous absence of internal gate-keeping policies and practices. While fencing is practiced in public places, somehow to appease the native citizens and almost terrorise the (irregular) migrants, effective gate-keeping that would affect not only irregular migrants but also their employers is not implemented. Here we need however to acknowledge the ambivalent role of native families in Italy and Greece who may be at the same time fervent opponents of immigration but also anxious employers in dire need of the immigrant labour force, especially for the elderly and the children.

The repeated implementation of large regularisation programmes by both Italy and Greece during the past 20 years is but a confirmation of this internal contradiction between a dramatic rhetoric against irregular immigration and a rather lax attitude towards the informal employment of both legal and undocumented migrants. It is however worth noting that this is not only a typical aspect of the

Maroukis, T. (2008). CLANDESTINO project report, ELIAMEP, Athens, Greece, available at http:// clandestino.eliamep.gr last accessed on 24 June 2011. 
so called 'southern model of immigration'; ${ }^{61}$ but also a more general feature of contemporary international migration in the European Union. According to the REGINE project, during the decade 1998-2008, 22 out of 27 EU Member States implemented some programme of regularization of unauthorized residents. Of the five Member States that did not implement any regularisation, three were new Member States little affected by immigration. ${ }^{62}$

61) King, R. and Black, R. (1997). Southern Europe and the New Immigration, Brighton: Sussex Academic Press; King, R. and N. Ribas-Mateos (2002). 'Toward a diversity of migratory types and contexts in Southern Europe', Studi emigrazione/Migrations Studies, 39/145, pp. 5-25.

62) International Centre for Migration Policy Development (ICMPD) (2009). REGINE. Regularisations in Europe. Study on practices in the area of regularisation of illegally staying third-country nationals in the Member States of the EU. Final Report, Vienna: ICMPD. 
